\title{
Identification of pituitary-specific transcription factor-1 (PIT-1) and leptin gene (LEP) polymorphism of Holstein cattle reared in Turkey
}

\author{
Davut BAYRAM ${ }^{1}$, Korhan ARSLAN ${ }^{2}$, Bilal AKYÜZ ${ }^{2}$, Kaan Muhsin IŞCAN ${ }^{1}$ \\ ${ }^{11}$ Erciyes University, Department of Animal Breeding and Husbandary, Faculty of Veterinary Medicine; ${ }^{2}$ Department of Genetics, \\ Kayseri, Turkey.
}

\begin{abstract}
Summary: Purpose of this study was to examine leptin $(L E P)$ and pituitary-specific transcription factor-1 (Pit-I) gene polymorphisms in Holstein cattle $(\mathrm{n}=352)$ in Turkey. In order to determine the Pit-I-HinfI and LEP-Sau3AI polymorphisms, polymerase chain reaction and restriction fragment length polymorphism (PCR-RFLP) were performed. A 600 bp length fragment of Pit-I and a 422 bp length fragment of $L E P$ were amplified. In this study, two types of alleles, A and B, for both of the Pit-I and $L E P$ genes were observed. The highest frequencies of the alleles were estimated, and were the B allele (0.68) for the Pit-I gene and the A allele (0.87) for the LEP gene. According to the results of the chi-square test, a significant deviation from the Hardy-Weinberg equilibrium was determined for both of these genes in the investigated breed (in the same order; $X^{2}: 40.75, p<0.001$ and $X^{2}: 8.4, p<0.01$ ).

Keywords: Holstein, leptin, pit-I, polymorphism, RFLP.
\end{abstract}

\section{Türkiye'de yetiştirilen Holştayn sığırlarda hipofiz bezine özgü transkripsiyon faktörü- 1 (PIT-1) ve leptin (LEP) gen polimorfizmlerinin belirlenmesi}

Özet: Bu çalışmada Türkiye'de Kayseri civarında yetiştirilen Holştayn ırkı sığırlarda (n=352) leptin (LEP) ve hipofiz bezine özgü transkripsiyon faktörü -1 (Pit-I) genlerinin polimorfizmlerinin belirlenmesi amaçlanmıştır. Pit-I-HinfI ve LEP-Sau3AI polimorfizmlerinin belirlenmesi amacı ile polimeraz zincir reaksiyonu (PZR) ve restriksiyon parça uzunluk polimorfizm (RFLP) analizi yapılmıştır. Pit-1 geni için 600 bç'lik ve LEP geni için 422 bç'lik uzunluk amplifiye edilmiştir. Çalışmada, Pit-1 ve LEP geni allellerinin her ikisinde de A ve B allelleri olmak üzere iki iki tip allel gözlendi. En yüksek frekans Pit-1 geni için A allelinde (0.87), LEP geni için ise B allelinde (0.68) olarak belirlendi. Ki-kare test sonuçlarına gore, incelenen ırkta, her iki gende de Hardy-Weinberg dengesinden anlamlı bir sapma gözlendi (aynı sıra ile; $\mathrm{X}^{2}: 40.75$, $\mathrm{p}<0.001$ ve $\mathrm{X}^{2}: 8.4, \mathrm{p}<0.01$ ).

Anahtar sözcükler: Holştayn, leptin, pit-1, polimorfizm, RFLP.

\section{Introduction}

Due to the prolonged generation interval of cattle, genetic enhancement is difficult in dairy cattle breeding using current conventional selection methods. The development of effective methods for rapidly and accurately identifying breeding candidates is a priority for cattle breeders.

In recent years, developments in molecular genetics have revealed new methods for evaluating genetic changes. The genes and genotypes used in selection studies of livestock breeding, known as molecular markers or candidate genes, have been identified through modern molecular techniques. Candidate gene approaches and genome screening technologies have been used to determine quantitative trait loci (QTL) in livestock. These QTL may be critical to the genetic improvement of livestock. Several prominent studies have examined the relationship between genetic polymorphisms and various livestock efficiency traits $(19,47)$. Use of genetic polymorphisms and molecular markers may dramatically improve the speed and efficiency of livestock selection and breeding (8). Candidate genes are generally selected due to their physiological or biological effects on quantitative traits such as milk yield and live weight gain, or their physical association with the genes that affect these traits (41).

Many of the traits affecting agricultural efficiency are complicated and are strongly influenced by feeding and care of the animals. However, recent developments in molecular biology and biotechnology suggest that marker assisted selection (MAS) will enable more accurate and effective selection of traits (13). Litwińczuk et al. (23) reported the use of genetic markers for breeding selection results with a 5\% improvement in the time required to breed cattle.

The gene encoding leptin hormone may be used as a marker for dairy, meat and fertility yield. Leptin, also known as the hunger hormone, is secreted by the adipose 
tissue and is associated with the body condition score through the regulation of lipid metabolism (17). In cows, leptin concentration decreases during lactation but increases during the dry period, in parallel to fattening. A linear correlation among leptin concentration and energy balance, body condition score (BCS) and the level of fattening has been reported (1). Leptin encoding gene (LEP) is on the $4^{\text {th }}$ chromosome of the cattle karyotype. Comprising three exons and two introns, this gene has been extensively investigated in several species due to its role in mammalian metabolism (40). Specific single nucleotide polymorphisms (SNPs) in the LEP gene have been associated with traits important for yield. For example, LEP polymorphisms have been linked to fertility and growth traits in the Holstein cattle breed $(5,22)$ and to live weight gain and daily mean live weight gain in beef cattle breeds (20).

Another gene that may serve as a marker for meat yield in livestock is the pituitary-specific transcription factor (also known as Pit-I, POU1F1) gene. A member of the POU family of transcription factors, Pit-I regulates growth and development in animals (46). Located on the $1^{\text {st }}$ chromosome of the cattle karyotype, Pit-I plays a role in the development of hypophysis and the proliferation of somatic cells and in the secretion of growth hormone $(\mathrm{GH})$ and prolactin (PRL) hormone in mammals (2, 46). Absence or insufficient expression of Pit-I is associated with dwarfism in both humans and mice (34). Pit-I is thought to contribute to mammary gland development and milk production $(6,24,26)$.

Holstein cattle are the most important breed of cattle for milk production in Turkey. The total number of Holstein cattle has consistently increased in recent years. Male Holstein cattle are replacing local breeds, which were important sources of cattle meat in Turkey in the past. The aim of the present study is to examine $L E P$ and Pit-I gene polymorphisms using RFLP methods in the Holstein cattle breed, the most important milk and beef stock bred in Turkey.

\section{Materials and Methods}

Animals in this study consisted of 350 Holstein cattle reared in Turkey. Blood samples were collected from all cows into heparinized tubes for DNA isolation. The DNA used in the study was isolated using the phenolchloroform extraction method (37).

PCR for the Pit-I and LEP genes, PCR was performed in a $25 \mu \mathrm{l}$ reaction mixture containing $0.2 \mu \mathrm{M}$ of each gene's forward and reverse primers, $1.5 \mu \mathrm{l}$ genomic DNA template, $2 \mathrm{U}$ Taq polymerase, and $50 \mu \mathrm{M}$ dNTP mix. The thermal cycling conditions for Pit-I were as follows: an initial denaturation step at $95^{\circ} \mathrm{C}$ for $2 \mathrm{~min}$ followed by 30 cycles of $94^{\circ} \mathrm{C}$ for $45 \mathrm{~s}, 60^{\circ} \mathrm{C}$ for $1 \mathrm{~min}$, $72^{\circ} \mathrm{C}$ for $1 \mathrm{~min}$ and a final extension step at $72^{\circ} \mathrm{C}$ for 3 min. The PCR products were digested with HinfI restriction endonuclease (Fermentas) (Table 1). The PCR products and restriction fragments were electrophoresed on $2 \%$ agarose gels respectively, and the allelic structure of the examined individuals and the genotypes were determined.

Thermal cycling conditions for LEP were as follows: an initial denaturation step at $94^{\circ} \mathrm{C}$ for 2 min followed by 35 cycles of $94^{\circ} \mathrm{C}$ for $1 \mathrm{~min}, 55^{\circ} \mathrm{C}$ for $1 \mathrm{~min}, 72^{\circ} \mathrm{C}$ for 1 min and a final extension step at $72^{\circ} \mathrm{C}$ for $15 \mathrm{~min}$. The PCR products were digested with Sau3AI restriction endonuclease (Fermentas) (Table 1). The PCR products and restriction fragments were electrophoresed on $2 \%$ agarose gels respectively, and the allelic structure of the examined individuals and the genotypes were determined.

The allele and genotype frequencies were estimated by direct counting. The heterozygosity (as gene variation indicates) were calculated using the POPGENE software version 1.31 (45), according to Nei procedure (29).

\section{Results}

PCR performed for the Pit-I gene produced a single band of 600 bp length for the samples assayed (Figure 1). Following enzymatic digestion with HinfI endonuclease for the Pit-I gene, in animals of homozygote AA genotype a single band of $600 \mathrm{bp}$ was observed; in animals of the homozygote BB genotype two bands of a length of $243 \mathrm{bp}$ and $357 \mathrm{bp}$ were observed in animals of the $\mathrm{AB}$ genotype three bands of 243, 357 and $600 \mathrm{bp}$ length were observed. Following enzymatic digestion with HinfI the frequencies of genotypes were found $17.62 \%$ for AA $28.69 \%$ for $\mathrm{AB}$, and $53.69 \%$ for $\mathrm{BB}$. The $\mathrm{B}$ allele $(0.68)$ frequency was found to be higher than that of the A allele (0.32) (Table 2).

Table 1. Primers and amplification conditions. Tablo 1. Primerler ve amplifikasyon koşulları.

\begin{tabular}{|l|l|c|c|c|}
\hline & Primer Sequence & Annealing temperature $\left({ }^{\circ} \mathrm{C}\right)$ & Product size $(\mathrm{bp})$ & Restriction enzyme \\
\hline \multirow{2}{*}{ Pit-I } & $\begin{array}{l}\text { GAGCCTACATGAGACAAGCAC } \\
\text { AAATGTACAATGTGCCTTCTGA }\end{array}$ & 60 & 600 & HinfI \\
\hline \multirow{2}{*}{ LEP } & $\begin{array}{l}\text { TGGAGTGGCTTGTTATTTTCTTCT } \\
\text { GTCCCGCTTCTGGCTACCTAACT }\end{array}$ & 55 & 422 & Sau3AI \\
\hline
\end{tabular}




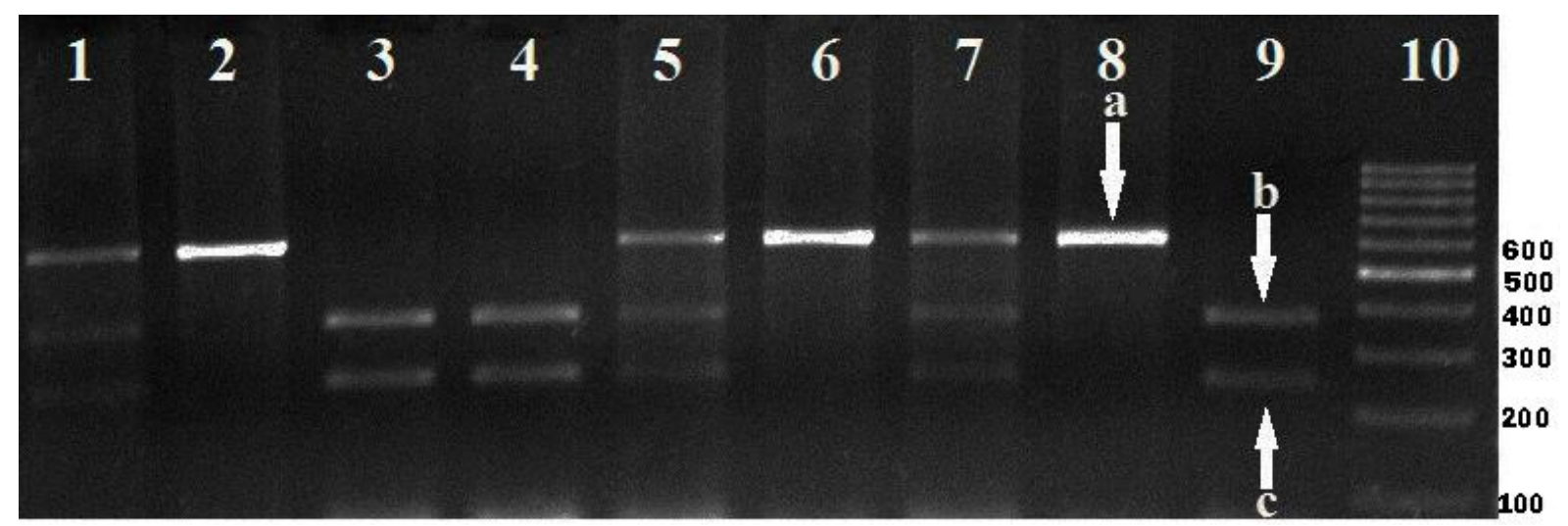

Figure 1. HinfI endonuclease enzyme digestion products of different PIT-1 genotypes. 10; 100 bp DNA ladder: 2, 6 and 8; individuals of the AA (600 bp) genotype: 3, 4 and 9 individuals of the BB; (243, $357 \mathrm{bp}$ ) genotype: 1, 5 and 7; individuals of the AB (243, 357 , 600 bp) genotype; a:600 bp, b:357 bp, c: 243 bp.

Şekil 1. HinfI enzimi ile kesim sonucu elde edilen farklı PIT-1 genotipleri. 10; 100 bç'lik DNA cetveli; 2, 6 ve 8; AA (600 bç) genotipli bireyler: 3, 4 ve 9 BB; (243, 357 bç) genotipli bireyler: 1, 5ve 7; AB (243, 357, 600 bç) genotipli bireyler; a:600 bç, b:357 bç, c: 243 bç.

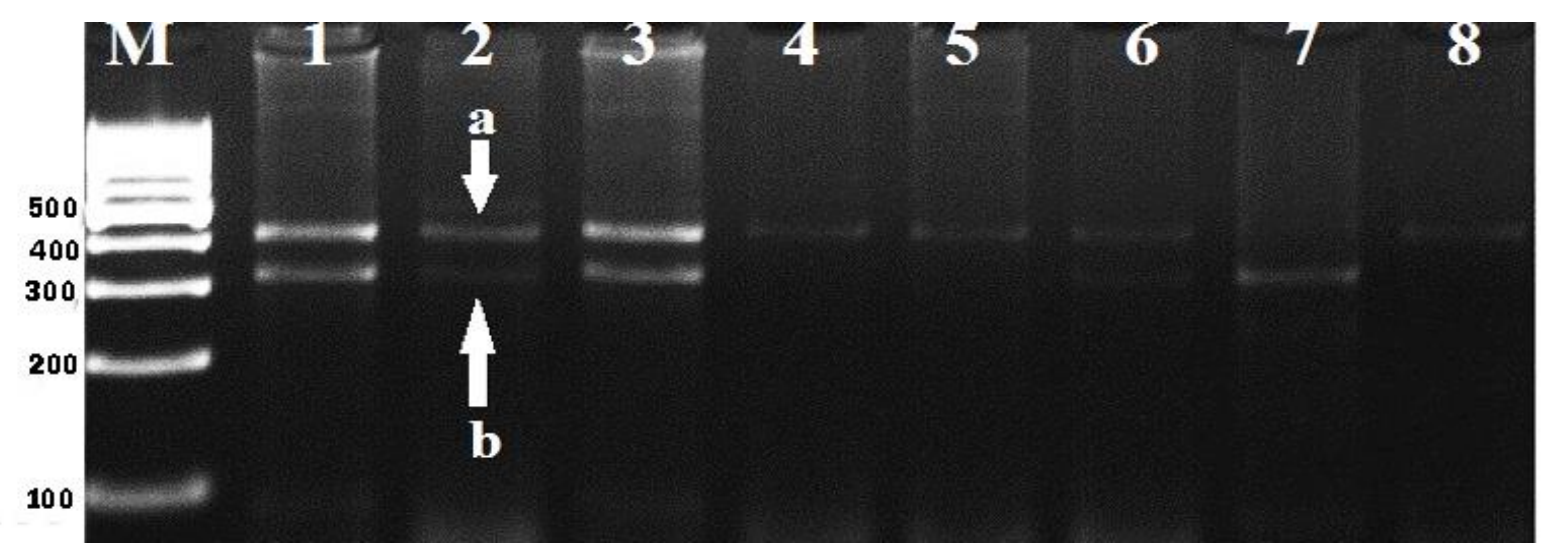

Figure 2. Sau3AI endonuclease enzyme digestion products of different LEP genotypes. M; 100 bp DNA ladder: 4, 5, 6 and 8; individuals of the AA (390 bp) genotype: 7 individual of the BB; (303 bp) genotype: 1, 2 and 3; individuals of the AB (303, $390 \mathrm{bp)}$ genotype a: 390 bp, b: 303bp.

Şekil 2. Sau3AI enzimi ile kesim sonucu elde edilen farklı LEP genotipleri. M; 100 bç'lik DNA cetveli; 4, 5, 6 ve 8; AA (390 bç) genotipli bireyler: 7 BB; (303 bç) genotipli birey: 1, 2 ve 3; AB (303, 390 bç) genotipli bireyler a: 390 bç, b: 303 bç.

Table 2. Allele frequencies and chi-square results of Pit-I and $L E P$ genes.

Tablo 2. Pit-I ve LEP genlerinin allel frekansları ve Ki-kare sonuçları.

\begin{tabular}{|c|c|c|c|c|c|c|c|c|c|c|c|}
\hline \multirow{3}{*}{ Gen } & \multirow{3}{*}{$\mathrm{n}$} & \multicolumn{6}{|c|}{ Genotype } & \multicolumn{2}{|c|}{$\begin{array}{c}\text { Allele } \\
\text { Frequency }\end{array}$} & \multirow{3}{*}{$X^{2}$} & \multirow{3}{*}{$\begin{array}{c}X^{2} \\
\text { P Value }\end{array}$} \\
\hline & & \multicolumn{2}{|c|}{ AA } & \multicolumn{2}{|c|}{$\mathrm{AB}$} & \multicolumn{2}{|c|}{$\mathrm{BB}$} & A & B & & \\
\hline & & Obs (Exp) & $\mathrm{F}(\%)$ & Obs (Exp) & $\mathrm{F}(\%)$ & Obs (Exp) & $\mathrm{F}(\%)$ & & & & \\
\hline Pit I & 352 & $\begin{array}{c}62 \\
(35.96)\end{array}$ & 17.62 & $\begin{array}{c}101 \\
(153.09)\end{array}$ & 28.69 & $\begin{array}{c}189 \\
(162.96)\end{array}$ & 53.69 & 0.32 & 0.68 & 40.75 & $\mathrm{p}<0.001$ \\
\hline$L E P$ & 352 & $\begin{array}{c}273 \\
(266.88)\end{array}$ & 75.82 & $\begin{array}{c}67 \\
(79.24)\end{array}$ & 22.51 & $\begin{array}{c}12 \\
(5.88)\end{array}$ & 1.67 & 0.87 & 0.13 & 8.4 & $\mathrm{p}<0.01$ \\
\hline
\end{tabular}

Following enzymatic digestion with Sau3AI endonuclease for the LEP gene, in animals of a homozygote AA genotype two bands of $32 \mathrm{bp}$ and $390 \mathrm{bp}$ were observed; in animals of the $\mathrm{AB}$ genotype four bands of 32, 88, 303 and $390 \mathrm{bp}$ were observed; in animals of the homozygote BB genotype three bands of 32, 88 and 303 bp length were observed. However agarose gel electrophoresis of 303 and 309 bp bands together or individually seen were not an issue in determining the genotype. Reason to be very small 32 and 88 bp bands could not be displayed (Figure 2). 
PCR performed for the LEP gene produced a single band of 422 bp length for the samples assayed. Following enzymatic digestion with $\mathrm{Sau} 3 \mathrm{Al}$, frequencies of genotypes were found as $75.82 \%$ for $\mathrm{AA}, 22.51 \%$ for $\mathrm{AB}$ and $1.67 \%$ for BB (Table 2).

\section{Discussion and Conclusion}

Maximizing yield and efficiency while minimizing cost is a primary goal of animal husbandry. This can only be achieved under ideal environmental conditions and through the use of highly efficient animals. In practice, good animal husbandry is a highly complex process involving the selective breeding of high yield animals, the use of suitable selection methods for improving yield traits, and the management of all associated costs. For traits like milk and meat yield, the selection of the breeding candidates according to their production records requires the examination of mature animals. Raising animals to maturity for selection purposes results in unnecessary care costs for animals that are likely to be excluded from breeding. In breeding animals, environmental factors cannot be expected to have the same level of influence on yield. The use of genetic markers during selection may reduce the influence of environmental factors in biasing breeding selection. The genetic variations in yield traits are distributed throughout many genes, each having a relatively small effect. The aim of this study was to evaluate the presence of polymorphisms in the Pit-I and LEP genes and their frequency in Holstein cattle, the most commonly bred cattle in Turkey. Female Holsteins are used for milk production and the male calves are used for meat production.

Pit- 1 has been associated with milk yield traits in cattle due to its effects on growth hormone production and prolactin hormone secretion. A previous study examined the relationship between the Pit-1-HinfI polymorphism and milk yield traits in Holsteins bred in Italy. In that study, the A Allele was positively correlated with milk and milk protein yield and negatively associated with milk fat yield (36). Similarly, Oshima and Barreras (31) reported a positive correlation between the Pit-1-HinfI-AA genotype and milk yield in Holsteins. Oshima and Barreras (31) declared that high milk yield in animals with the AA genotype may not have been due to the A allele alone, but also due to the positive effects of Pit-1 on the other genes influencing milk yield. In a study of Holsteins bred in Iran, individuals with the $\mathrm{AB}$ genotype were reported to yield higher amounts of milk when compared with the other genotypes (12). Edriss et al. (11) reported that the Pit-1HinfI-BB genotype was the most common genotype among Holsteins (0.519) and that this genotype had a negative effect on milk fat and milk protein yield.
Similar to studies conducted on Holsteins, the A allele was reported to have positive effects on milk yield and milk yield traits in Simmental cattle $(7,42)$, Gyr cattle (25), Brown Swiss cattle as well as (2) Holstein cattle.

Previous studies evaluating Pit-1-Hinf polymorphism in Holsteins bred in Iran $(9,12)$, Poland (10), Italy (36) and China (43) found that the frequency of the Pit-1-B allele was much higher than that of the A allele frequency at 0.830 and 0.70 , respectively. In the present study of Holstein cattle, BB was genotype found at the highest frequency with a value between 0.569 and 0.742 and the AA genotype was present at the lowest frequency, between 0.007 and 0.054 . Similar to previous studies, the frequency of the B allele (0.68) was higher than that of the A allele (0.32). In contrast to studies conducted in other countries, our data show that the AA genotype frequency is relatively high (0.176) in Holstein cattle bred in Turkey. The reason for the higher frequency of the A allele and AA genotypes among Holsteins in Turkey is thought to be due to the relationship between this genotype and milk yield traits. According to Turkish Statistical Institute (TÜIK) data, the annual milk yield per animal increased from 2900 $\mathrm{kg}$ in 2000 to $3900 \mathrm{~kg}$ by 2014. In addition to improvements in animal care and feeding conditions, the relatively high frequency of the Pit-1-HinfI A allele among Turkish Holsteins may account for improved yields. Pit-1-HinfI A allele and AA genotype frequencies were higher in the Holstein cattle bred in Turkey relative to prior studies conducted in other countries. The data presented in the present study on Pit-1-HinfI polymorphism frequency thus represents a deviation from the Hardy-Weinberg equilibrium.

Another gene that has been associated with yield traits in livestock is the LEP gene. Encoded by the LEP gene, also known as the obesity gene, leptin is a $16-\mathrm{kDa}$ protein secreted by adipose tissue that plays important roles in many physiological events such as growth, the regulation of the immune system, milk yield and reproduction $(3,18,38)$. Generally speaking, $L E P$ is a strong candidate gene for economically important traits such as milk yield, meat quality, feed intake and reproductive functions (27). In the first study conducted on this topic, Jiang \& John found that the LEP gene was associated with back fat thickness (16). LEP-Sau3AI polymorphism was associated with live weight in local cattle breeds in China and cattle with the BB genotype had better growth traits, making this gene a potentially interesting target for selective breeding (44). LEP-Sau3AI polymorphism was also linked to growth characteristics in a study conducted in Limousin cattle $(20,33)$. Passos et al. (33) examined Aberdeen Angus x Nellore crossbred beef, reporting that $L E P$ polymorphism influenced the level of leptin expression in adipose tissue. In addition, LEP- 
Sau3AI polymorphism has been associated with calving intervals and first calving weight in Aberdeen Angus $\mathrm{x}$ Nellore crossbred cattle, with the A allele specifically increasing the calving interval (1). Similarly, a study examining the relationship between LEP-Sau3AI polymorphism and fertility among Holsteins reported that individuals with the $\mathrm{AB}$ genotype had better reproductive performance when compared to other genotypes and that the $\mathrm{B}$ allele, which does not have a negative effect on fertility, may be the allele of choice for increased milk yield (28). Another study evaluating the effect of LEPSau3AI polymorphism on feed intake and milk yield in Holstein cattle found that animals with the $\mathrm{AB}$ genotype consumed $0.73 \mathrm{~kg}$ more feed per day compared with those with an AA genotype and yielded $1.32 \mathrm{~kg}$ more milk per day (21). The Milk fat yield of individuals with the AA LEP-Sau3AI polymorphism was lower than that of cattle with the $\mathrm{AB}$ genotype, although total milk yield was unchanged (14). Another SNP in the LEP gene, detected using the Kpn2I enzyme, has been associated with milk protein yields (4). Studies conducted on different livestock show that $L E P$ is an important candidate gene linked to various yield traits. Thus, the characterization of LEP genotypes and selection in a given population may be an effective means of increasing yields.

In a study investigating $L E P$-Sau3AI polymorphism in Holsteins bred in Iran, the AA genotype frequency (0.90) and A allele frequency (0.95) were the most common and the BB genotype was not found (14). In another study examining LEP-Sau3AI polymorphism in 112 Holstein cattle raised in Iran, A allele frequency and $\mathrm{B}$ allele frequency were 0.798 and 0.202 respectively. In the same study, the frequencies of the AA genotype, AB genotype and BB genotypes were 0.607, 0.38 and 0.202, respectively (39). In a study conducted on Holsteins bred in Greece, the frequency of the $\mathrm{AA}$ and $\mathrm{AB}$ genotypes were 0.78 and 0.22 , respectively, while the $\mathrm{BB}$ genotype was not detected. The $\mathrm{A}$ and $\mathrm{B}$ allele frequencies were 0.89 and 0.11 , respectively (30). In their study investigating LEP-Sau3AI polymorphism in Holstein cattle, Pomp et. al determined that the A allele frequency (0.71) was higher than that of the B allele (35). In another study conducted on Holsteins bred in China, the frequencies of the $\mathrm{A}$ and $\mathrm{B}$ alleles were found to be 0.615 and 0.385 , respectively (44). In a study including 149 Holstein cows in Turkey, Özdemir (32) determined that the frequencies of the $\mathrm{AA}, \mathrm{AB}$ and $\mathrm{BB}$ genotypes were $0.92,0.07$ and 0.01 respectively, and that the A allele frequency was comparatively high (0.95).

In the present study conducted on 352 Holstein cows in Turkey, the AA genotype frequency (0.758) was more common than other genotypes. However, in contrast to Özdemir's previous study in Turkey (32), BB (0.167) and
AB (0.225) genotype frequencies were relatively more common. These higher frequency values may be due to a better representation of the Holstein breed in Turkey, resulting in a larger sample size. On the other hand, although no conscious selection of LEP-Sau3AI polymorphism was made on the Holstein cows examined in this study, B allele frequency may be elevated as a result of the selection of female calves with high milk yield and male calves with high live weight gain. In previous studies, AA genotype was reported to have a negative effect on milk yield $(21,28)$ and live weight gain (1) while BB genotype was associated with improved body condition score. Upon consideration of the results of prior studies $(15,39,44)$ in addition to this one, we speculate that breeders artificially increased B allele frequency through their selection of female calves with high milk yield. This study and similar studies of LEP-Sau3AI polymorphism in Holstein cattle bred in different countries show that AA genotype is the most common. BB genotype is either seen at very low frequencies or not encountered at all.

Maximum yield and efficiency with minimum cost are the primary goals of animal husbandry. Needs of the animals may vary according to their genotype and only the strongest genetic markers can serve as practical tools for breeders. Selection of animals based on yield records under optimal environment conditions requires that dairy and beef animals be of a certain age in order to determine yield and therefore breeding selection. This development time results in unnecessary care costs for animals which are likely to be excluded from breeding. Due to their genetic differences, environment will have varying impacts on breeding candidates. Effects of genotype variations should be minimized. Recently, use of genetic markers during selection has become one of the most effective methods for avoiding the biased effects of environmental variation while increasing the chance of developing a useful variant.

Holstein cattle are bred by most of the milk and red meat producing operations in Turkey. Holsteins are the mostportly breed among common dairy breeds. Male Holsteins are largely used for meat production, although a small minority may be more useful for breeding. In combination meat-milk production, selection of on-site born male calves with LEP-AA genotypes for feeding may contribute to an increase in carcass yield and meat flavour. In combination meat-milk operations, selection of animals with LEP-AB genotypes may result in balanced benefits to both meat and milk production. Cattle populations that carry a high frequency of Pit-I-AA and LEP-BB genotypes may be considered for breeding in enterprises that primarily produce milk. Relationship between cattle phenotype and genotype should be further evaluated. 


\section{Acknowledgement}

This study was supported by Scientific Research Committee of Erciyes University (BAP) (Project no: TSA09-1032).

\section{References}

1. Almeida S, Almeida E, Moraes J, et al. (2003): Molecular markers in the LEP gene and reproductive performance of beef cattle. J Anim Breed Genet, 120, 106-113

2. Aytekin I, Boztepe S (2013): Associations of Pit-1 gene polymorphism with milk yield and composition traits in Brown Swiss cattle. J Anim Plant Sci, 23, 1281-1289.

3. Block S, Butler W, Bell A, et al. (2001): Decreased concentration of plasma leptin in periparturient dairy cows is caused by negative energy balance. J Endocrinol, 171, 339-348.

4. Buchanan F, Van Kessel A, Waldner C, et al. (2003): Hot topic: An association between a leptin single nucleotide polymorphism and milk and protein yield. J Dairy Sci, 86, 3164-3166.

5. Clempson AM, Pollott GE, Brickell JS, et al. (2011): Evidence that leptin genotype is associated with fertility, growth, and milk production in Holstein cows. J Dairy Sci, 94, 3618-3628.

6. Cohen LE, Wondisford FE, Radovick S (1997): Role of Pit-I in the gene expression of growth hormone, prolactin, and thyrotropin. Endocrinol Metab Clin N Am, 25, 23-540.

7. Cosier V, Vlaic A, Gaboreanu I (2007): HinfI polymorphism of $k$-casein and Pitl genes in Romanian Simmental cattle. Sci P Anim Sci Bio, 40, 59-64.

8. Dario C, Selvaggi M, Carnicella D, et al. (2009): Bufano G: STAT5A/Aval polymorphism in Podolica bulls and its effect on growth performance traits. Livest Sci, 123, 83-87.

9. Doosti A, Arshi A, Bomeni B (2011): Molecular study of PIT1 gene polymorphism in Holstein and Iranian native cattle. Ajar, 6, 4467-4470.

10. Dybus A, Szatkowska I, Czerniawska-Piatkowska E, et al. (2004): PIT1-HinfI gene polymorphism and its associations with milk production traits in polish Blackand-White cattle. Arc Tierzucht, 47, 557-564.

11. Edriss MA, Edriss V, Rahmani HR (2009): Association of PIT-1 gene polymorphism with birth weight, milk and reproduction traits in Isfahan Holstein cows. Arch Tierzucht, 52, 445-447.

12. Heidari M, Azari M, Hasani S, et al. (2012): Effect of polymorphic variants of $G H, P i t-1$, and $\beta-L G$ genes on milk production of Holstein cows. Russ J Genet, 48, 417-421.

13. Hua GH, Chen SL, Yu JN, et al (2009): Polymorphism of the growth hormone gene and its association with growth traits in Boer goat bucks. Meat Sci, 81, 391-395.

14. Javanmard A, Khaledi K, Asadzadeh N, et al. (2010): Detection of polymorphism in the bovine leptin (LEP) gene: Association of a single nucleotide polymorphism with breeding value of milk traits in Iranian Holstein cattle. J Mol Genet, 2, 10-14.

15. Javanmard A, Mohammadabadi MR, Zarrigabayi GE, et al. (2008): Polymorphism within the intron region of the bovine leptin gene in Iranian Sarabi cattle (Iranian Bos taurus). Russ J Genet, 44, 495-497.
16. Jiang Z, Gibson JP (1999): Genetic polymorphisms in the leptin gene and their association with fatness in four pig breeds. Mamm Genome, 10, 191-193.

17. Kaçar C, Arı UÇ (2007): Leptinin inek ve koyunlarda enerji metabolizmasi ve üreme fizyolojisi üzerine etkileri. Kafkas Univ Vet Fak, 13, 209-213.

18. Kadokawa H, Blache $D$, Yamada $Y$, et al. (2000): Relationships between changes in plasma concentrations of leptin before and after parturition and the timing of first post-partum ovulation in high-producing Holstein dairy cows. Reprod Fertil Dev, 12, 405-411.

19. Khatami SR, Lazebnyı̌ OE, Maksimenko VF, et al. (2005): Association of DNA polymorphisms of the growth hormone and prolactin genes with milk productivity in Yaroslavl and Black and White cattle. Genetika, 41, 229236.

20. Kulig H, Kmiec M (2009): Association between leptin gene polymorphisms and growth traits in Limousin cattle. Russ J Genet, 45, 738-741.

21. Liefers SC, te Pas MF, Veerkamp RF, et al. (2002): Associations between leptin gene polymorphisms and production, live weight, energy balance, feed intake, and fertility in Holstein heifers. J Dairy Sci, 85, 633-1638.

22. Liefers SC, Veerkamp RF, te Pas MF, et al. (2005): Leptin promoter mutations affect leptin levels and performance traits in dairy cows. Anim Genet, 36, 111-118.

23. Litwinczuk Z, Krol J (2002): Polymorphism of main milk proteins in beef cattle maintained in East-Central Poland. Anim Sci Pap Rep, 1, 33-40.

24. Mangalam HJ, Albert VR, Ingraham HA, et al. (1989): A pituitary POU domain protein, Pit-1, activates both growth hormone and prolactin promoters transcriptionally. Gene Dev, 3, 946-958.

25. Mattos KK, Del Lama SN, Martinez ML, et al. (2004): Association of $b G H$ and Pit-1 gene variants with milk production traits in dairy Gyr bulls. Pesq Agropec Bras, 39, 147-150.

26. Moody DE, Pomp D, Barendse W (1995): Restriction fragment length polymorphism in amplification products of the bovine PIT1 gene and assignment of PIT1 to bovine chromosome 1. Anim Genet, 26, 45-47.

27. Moravčíková N, Trakovická A, Kasarda R (2012): Polymorphism within the intron region of the bovine leptin gene in Slovak Pinzgau cattle. J Anim Sci Biotechnol, 45, 211-214.

28. Moussavi A, Ahouei M, Nassiry M, et al. (2006): Association of leptin polymorphism with production, reproduction and plasma glucose level in Iranian Holstein cows. Asian-Aust J Anim Sci, 19, 627-631.

29. Nei M (1978): Estimation of average heterozygosity and genetic distance from a small number of individuals. Genetics, 89, 583-590.

30. Oikonomou G, Angelopoulou K, Arsenos G, et al. (2008): The effects of polymorphisms in the DGAT1, leptin and growth hormone receptor gene loci on body energy, blood metabolic and reproductive traits of Holstein cows. Anim Genet, 40, 10-17.

31. Oshima S, Barreras A (2003): Relationships between DGAT1 and Pit-1 genes polymorphism and milk yield in Holstein cattle. J Anim Sci, 54, 1-3. 
32. Özdemir M (2011): Genetic polymorphism of leptin gene in Holstein and native East Anatolian Red (EAR)cattle raised as genetic resource in Turkey. Afr J Agric Res, 6 , 6008-6010.

33. Passos DT, Hepp D, Moraes JCF, et al. (2007): Effect of polymorphisms linked to LEP gene on its expression on adipose tissues in beef cattle. J Anim Breed Genet, 124, 157-162.

34. Pfaffle RW, Dimattia GE, Parks JS, et al. (1992): Mutation of the Pou-specific domain of Pit-1 and hypopituitarism without pituitary hypoplasia. Science, 257, 1118-1121.

35. Pomp D, Zou T, Clutter AC, Barendse W (1997): Rapid communication: Mapping of leptin to bovine chromosome 4 by linkage analysis of a PCR-based polymorphism. J Anim Sci, 75, 1427.

36. Renaville R, Gengler N, Vrech E, et al. (1997): Pit-1 gene polymorphism, milk yield, and conformation traits for Italian Holstein-Friesian bulls. J Dairy Sci, 80, 3431-3438.

37. Sambrook J, Fritsch E, Maniatis T (1989): Molecular cloning: A laboratory manual, $\left(2^{\text {nd }}\right)$ ed. Cold Spring Harbor Laboratory Press, Cold Spring Harbor, N.Y.

38. Santos-Alvarez J, Goberna R, Sanchez-Maralet V (1999): Human leptin stimulates proliferation and activation of human circulating monocytes. Cell Immunol, 194, 6-11.

39. Sharifzadeh A, Doosti A (2010): Genetic polymorphism at the leptin gene in Iranian Holstein cattle by PCR-RFLP. J Microbiol Res, 4, 1343-1345.

40. Silva DB, Crispim BA, Silva LE, et al. (2014): Genetic variations in the leptin gene associated with growth and carcass traits in Nellore cattle. Genet Mol Res, 13, 30023012 .
41. Unanian MM, Barreto CC, Cordeiro CMT, et al. (2002): Possible associations between bovine growth hormone gene polymorphism and reproductive traits. Braz Arch Biol Techn, 45, 293-299.

42. Viorica C (2006): RFLP/HinfI polymorphism between exon 5 and exon 6 of the PIT-1 gene in Romanian Simmental cattle. Usamv Journal-Cn, 63, 219-222.

43. Yan L, Fang X, Zhang R, et al. (2011): Analysis of pituitary specific transcription factor-1 gene polymorphism in several indigenous Chinese cattle and crossbred cattle. $\mathrm{J}$ Appl Anim Res, 39, 269-274.

44. Yang D, Chen H, Wang X, et al. (2007): Association of polymorphisms of leptin gene with body weight and body sizes indexes in Chinese indigenous cattle. J Genet Genomics, 34, 400-405.

45. Yeh FC, Yang R, Boyle T (1999): POPGENE Version 1.31. Microsoft Window-based free software for Population Genetic Analysis, University of Alberta. Edmonton, AB, Canada.

46. Zhang CL, Liu B, Chen H, et al. (2009): Associations of a HinfI PCR-RFLP of POU1F1 gene with growth traits in Qinchuan cattle. Anim Biotechnol, 20, 71-74.

47. Zhang L, Liu J, Zhao F, et al. (2013): Genome-wide association studies for growth and meat production traits in sheep. PloS one, 8, e66569.

Geliş tarihi: 05.01.2016 / Kabul tarihi: 14.10.2016
Address for correspondence:
Assist. Prof. Dr. Davut BAYRAM
Erciyes University, Faculty of Veterinary Medicine,
Department of Animal Breeding and Husbandary,
Kayseri, Turkey.
e-mail:vetdavut@gmail.com 